\title{
THE MOTILITY OF THE PELVIC COLON FOLLOWING COMPLETE LESIONS OF THE SPINAL CORD
}

\author{
By A. M. Connell, H. Frankel, L. Guttmann \\ National Spinal Injuries Centre, Stoke Mandeville Hospital, Aylesbury, \\ Bucks, England. M.R.C. Gastrointestinal Research Unit, Central \\ Middlesex Hospital, London, N.W. Io
}

\section{INTRODUCTION}

IT has been known for a long time that the motility of the gastro-intestinal tract of animals can be affected by lesions of the spinal cord, since Lister (I858) demonstrated the inhibitory action of the sympathetic system on peristalsis in the rabbit. Bayliss and Starling (1900) showed that pithing of the cord resulted in increased gut motility, and Elliott and Barclay-Smith (1904) reported similar findings. Of particular interest are Garry's studies (1933) on decerebrate cats. He demonstrated increased activity of the hind gut following section of the lumbo-sacral roots and also during spinal anaesthesia and postulated an inhibitory centre for gut movements in the lumbo-sacral cord.

Studies in man have been concerned mainly with the rectal and colonic response to distension since Masius (1868) and Gowers (1877) recorded reflex activity of the sphincter ani in response to rectal distension. The effects of rectal distension on sphincter function were reported in detail by Denny Brown and Robertson (1935), who concluded that the mechanism controlling defaecation is mediated through the lower sacral segments of the spinal cord and its peripheral plexus. This is in accordance with the findings of White, Verlich and Ehrenthal (1940), who recorded the pressure curve during slow filling of the colon with warm water in patients with lesions at various levels of the spinal cord. They found that reflex activity and ability to empty the colon effectively persists until the reflex centre in the sacral cord and its peripheral pathways have been injured.

These earlier studies, however, did not report the unstimulated colonic motility in paraplegic patients of various levels, nor were they concerned with the immediate effects of spinal cord transection on intestinal function. Guttmann (1959), reviewing the effects of spinal cord injuries on intestinal function, drew special attention to disorders of motility in the early stages following injury to the cervical cord. The initial effect is complete retention of faeces, while meteorism may develop rapidly resulting in dangerous interference with the function of the diaphragm, thus increasing the respiratory distress of the quadriplegic patient already resulting from the paralysis of the intercostal muscles.

The present paper records studies on the motility of the pelvic colon undertaken in 26 patients with complete lesions of the spinal cord following fracturedislocations of the spine or other causes. The objects of these studies were $(a)$ to determine differences in the resting motility of the colon resulting from injuries at different levels of the cord and $(b)$ to examine the effects of intrathecal alcohol block as well as various stimuli on colonic motility.

\section{CLINICAL MATERIAL}

All the 26 patients were male. Only patients with clinically complete transverse lesions of the spinal cord were examined. The motor and sensory levels corresponded in all cases except that in four of the cervical patients (Cases 6, 7, 8 


\begin{tabular}{|c|c|c|c|c|c|c|}
\hline Case No. & Age & Segmental level of cord lesion & $\begin{array}{l}\text { Time } \\
\text { since } \\
\text { onset }\end{array}$ & $\begin{array}{l}\text { Flaccid } \\
\text { or } \\
\text { spastic }\end{array}$ & Bowel function & Bladder function \\
\hline I. J. H. & 22 & Complete $\mathrm{C}_{5}$ due to fracture dislocation $\mathrm{C}_{4} / \mathrm{C}_{5}$ vertebrae & Io months & Spastic & is after & Coordinated automatic \\
\hline 2. A. B. & 22 & Complete $\mathrm{C} 6$ due to fracture dislocation $\mathrm{C}_{5} / \mathrm{C} 6$ vertebrae & 3 years & Spastic & Digital evace & Dis-coordinated \\
\hline 3. I. B. & $2 \mathrm{I}$ & Complete $\mathrm{C} 6$ due to fracture dislocation $\mathrm{C}_{5} / \mathrm{C} 6$ vertebrae & I year & Spastic & $\begin{array}{l}\text { Spontaneous after } \\
\text { suppositories }\end{array}$ & d automatic \\
\hline 4. D. G. & 26 & $\begin{array}{l}\text { Complete } \mathrm{C}_{7} \text { due to fracture dislocation } \mathrm{C}_{5} / \mathrm{C} 6 \text { vertebrae. } \\
\text { Active duodenal ulcer }\end{array}$ & 6 years & Spastic & Digital evacuation & $\begin{array}{l}\text { Dis-coordinated } \\
\text { automatic }\end{array}$ \\
\hline 5. M. J. & 22 & Complete $\mathrm{C}_{7}$ due to fracture dislocation $\mathrm{C} 6 / \mathrm{C}_{7}$ vertebrae & I year & Spastic & $\begin{array}{l}\text { Spontaneous after } \\
\text { suppositorites }\end{array}$ & Coordinated automatic \\
\hline 6. R. B. & 24 & Incomplete $\mathrm{C} 6$, complete $\mathrm{T}_{\mathrm{I}}$ due to fracture $\mathrm{C} 6$ vertebra & I year & Spastic & Sponta & Coordinated automatic \\
\hline 7. T. M. & 17 & $\begin{array}{l}\text { Incomplete } \mathrm{C} 6 \text {, complete } \mathrm{T}_{2} \text { due to fracture dislocation } \\
\mathrm{C}_{5} / \mathrm{C} 6 \text { vertebrae }\end{array}$ & 9 months & Spastic & $\begin{array}{l}\text { Spontaneous after } \\
\text { suppositories }\end{array}$ & Coordinated automatic \\
\hline 8. J. H. & 22 & $\begin{array}{l}\text { Incomplete } \mathrm{C}_{7} \text {, complete } \mathrm{T}_{2} \text { due to fracture dislocation } \\
\mathrm{C} 6 / \mathrm{C}_{7} \text { vertebrae }\end{array}$ & 5 months & Spastic & $\begin{array}{l}\text { Spontaneous after } \\
\text { suppositories }\end{array}$ & Coordinated automatic \\
\hline 9. L. H. & 37 & $\begin{array}{l}\text { Incomplete } \mathrm{C}_{7} \text {, complete } \mathrm{T}_{3} \text { due to fracture dislocation } \\
\mathrm{C}_{7} / \mathrm{T}_{\mathrm{I}} \text { vertebrae }\end{array}$ & 6 years & Spastic & Digital evacuation & $\begin{array}{l}\text { ordinated } \\
\text { matic }\end{array}$ \\
\hline го. D. B. & 29 & Complete $\mathrm{T}_{5}$ due to fracture dislocation $\mathrm{T}_{3} / \mathrm{T}_{4}$ vertebrae & 5 months & Spastic & heous after & Coordinated automatic \\
\hline I I. H. S. & 37 & Complete $\mathrm{T}_{7}$ due to fracture dislocation $\mathrm{T} 6 / \mathrm{T}_{7}$ vertebrae & 5 months & Spastic & $\begin{array}{l}\text { suppositorles } \\
\text { Spontaneous after } \\
\text { suppositories }\end{array}$ & Coordinated automatic \\
\hline I2. F. C. & 29 & $\begin{array}{l}\text { Complete } \mathrm{C}_{5} \text { due to fracture dislocation } \mathrm{C}_{4} / \mathrm{C}_{5} \text { vertebrae. } \\
\text { Low intrathecal alcohol block five years before investigation }\end{array}$ & $7 \mathrm{ye}$ & Flac & Digital & Atonic \\
\hline I3. L. S. & $2 \mathrm{I}$ & $\begin{array}{l}\text { Complete } \mathrm{C} 6 \text { due to fracture } \mathrm{C}_{5} \text { vertebra. Low intrathecal } \\
\text { alcohol block two months before investigation }\end{array}$ & I year & Flaccid & Digital evacuation & Atonic \\
\hline I4. J. B. & $5 \mathrm{I}$ & $\begin{array}{l}\text { Complete } \mathrm{T} 6 \text { due to fracture } \mathrm{T} 8 \text { vertebra. Low intrathecal } \\
\text { alcohol block eight years before investigation }\end{array}$ & Io years & Flaccid & ligital & Atonic \\
\hline I5. D. S. & 27 & Complete $\mathrm{T}_{9}$ due to fracture $\mathrm{T} 8$ vertebra & 6 months & Spastic & $\begin{array}{l}\text { Spontaneous after } \\
\text { suppositories }\end{array}$ & Coordinated automatic \\
\hline I6. T. D. & 27 & Complete $\mathrm{T}_{\mathrm{o}} \mathrm{o}$ due to fracture $\mathrm{T}_{9}$ vertebra & 9 months & Spastic & $\begin{array}{l}\text { Spontaneous after } \\
\text { suppositories }\end{array}$ & Coordinated automatic \\
\hline I7. T. C. & I 8 & Complete Tro due to fracture dislocation $\mathrm{T}_{\mathrm{ro}} / \mathrm{T}_{\mathrm{I}}$ i vertebrae & 9 months & Spastic & $\begin{array}{l}\text { ous after } \\
\text { itories }\end{array}$ & Coordinated automatic \\
\hline г $8 . \mathrm{H} . \mathrm{T}$. & 49 & Complete Ti I due to gun shot wound & I 5 years & Spastic & $\begin{array}{l}\text { Spontaneous after } \\
\text { suppositories }\end{array}$ & $\begin{array}{l}\text { Weak dis-coordinated } \\
\text { automatic }\end{array}$ \\
\hline I9. J. H. & 50 & Complete $T_{\text {I I }}$ due to haemangioma of spinal cord & I year & Spastic & $\begin{array}{l}\text { Spontaneous after } \\
\text { suppositories }\end{array}$ & Coordinated automatic \\
\hline 20. H. H. & 38 & Complete $T_{12}$ due to fracture dislocation $T_{I I} / T_{12}$ vertebrae & 9 months & Spastic & $\begin{array}{l}\text { Spontaneous after } \\
\text { suppositories }\end{array}$ & Coordinated automatic \\
\hline 2I. R. A. & 37 & $\begin{array}{l}\text { Complete } \mathrm{T}_{9} \text { due to cordectomy performed for removal of } \\
\text { astrocytoma }\end{array}$ & 5 months & Flaccid & Digital evacuation & Autonomous \\
\hline 22. O. T. & $5^{8}$ & $\begin{array}{l}\text { Complete below } \mathrm{T} 9 \text { due to haemangioma. Bilateral } \\
\text { cordotomy. Rhizotomy. Alcohol Block }\end{array}$ & 7 years & Flaccid & $\begin{array}{l}\text { evacuation } \\
\text { ional enema }\end{array}$ & Atonic \\
\hline 23. J. P. & 24 & Complete Ti I due to transverse myelitis & I y & Fla & Digital ev & At \\
\hline & 46 & Complete $\mathrm{T}_{12}$ due to fracture dislocation $\mathrm{T}_{12} / \mathrm{L}_{\mathrm{I}}$ vertebrae & $\begin{array}{l}5 \text { mont } \\
2 \text { years }\end{array}$ & Flac & $\begin{array}{l}\text { ation } \\
\text { lation }\end{array}$ & Atonic \\
\hline & 24 & Complete $\mathrm{L}_{\mathrm{I}}$ due to fracture $\mathrm{L}_{\mathrm{I}}$ vertebra & Io months & Flaccid & Digital evacuation & Atonic \\
\hline
\end{tabular}

FIG. I 
and 9, fig. I) there was slight sensory sparing down to $\mathrm{T}_{\mathrm{I}}, \mathrm{T}_{2}$ or $\mathrm{T}_{3}$ segments. There was no sacral sparing in any of the cases and there was complete loss of control of bladder, bowels and sexual functions. All patients had fully recovered from the initial general effects of their injury and from spinal shock. In each case, the injury had occurred at least five months before the study was carried out. Further clinical details of the patients studied have been set out in Figure I. Eleven patients had injuries of the cervical, upper or middle thoracic cord (I-I I, fig. I) and in these patients the motor paralysis was of spastic type with full reflex activity of the isolated cord. Twelve patients (15-26, fig. I) had lesions of the lower thoracic ( $\mathrm{T} 9$ or below) or lumbo-sacral cord. Of these, six had a motor paralysis of flaccid type and six a motor paralysis of spastic type.

A special group of four patients (I2, I3, I4, 22) had, in addition to their complete lesion of the spinal cord at higher level, a flaccid paralysis as a result of an intrathecal alcohol block (Guttmann, I947, I954). Three of them (12, I3, I4) were cervical or high thoracic cord lesions in whom the alcohol block was carried out because of intractable spasticity. The result of the block was a flaccid paralysis below Ti2. In these three patients, the colonic motility was studied at varying long intervals after the alcohol block (see fig. I). The fourth (Case 22) was first admitted in 1954 with a complete transverse spinal syndrome below TI2 due to haemangioma, verified at operation. In 1957 he had a bilateral cordotomy elsewhere because of intractable pain and spasm in the abdomen and legs, and in 1958 a bilateral anterior and posterior rhizotomy from Tio-S5. This operation resulted in a complete flaccid paraplegia below $\mathrm{T}_{9}$ but the abdominal pain persisted. Following intrathecal injection of $9 \mathrm{cc}$. absolute alcohol on 2 December I96I by one of us (L. G.), the pain disappeared but a feeling of abdominal tightness of spasmodic type returned. In this patient, the colonic motility was studied using a 'Radio Pill' before and five days after the alcohol block. In Case 2I a cordectomy below T9 was carried out elsewhere because of an astrocytoma.

All the patients were prepared for investigation by having their bowels open in the morning either spontaneously or by means of digital evacuation. Five patients had a meal during the course of a study and the motility recorded before and after the meal. None had an enema or laxative in the preceding 36 hours. In I3 patients the effect of rectal distension on the motility of the sigmoid colon was studied and in four the effect of bladder distension was examined.

Five patients had their colonic motility recorded on two or more different occasions.

\section{METHODS}

Technique of Recording Pressure. In all patients with one exception intraluminal pressures were recorded using miniature balloons, $7 \mathrm{~mm}$. in diameter and Io mm. in length (Atkinson, Edwards, Honour \& Rowlands, I957), connected by fine poly-ethylene tubing to a metal capsule optical manometer of high sensitivity (Rowlands, Honour, Edwards \& Corbett, I953). The total volume of the recording system is about I cc. and the change of volume with variation in pressure is very small. For this reason the system is highly sensitive and responds with accuracy to all frequencies encountered in the alimentary tract.

All studies were made with the patient relaxing on a bed in a quiet room. The subjects were encouraged to read light literature. No food was allowed for two hours before the beginning of the study. 
Without any prior preparation of the patient, a sigmoidoscope was passed to beyond the rectosigmoid angle without distending the colon with air. The tubes and recording balloons, still attached to the manometer, were passed into the colon through the sigmoidoscope, which was then withdrawn. The recording tips were placed routinely at 25,20 and $15 \mathrm{~cm}$. from the anus-i.e. they lie in the sigmoid, at the recto-sigmoid angle and in the upper rectum respectively (fig. 2). After placing the tube in the colon, half an hour was allowed to elapse before the recording began and this was continued for periods of up to five hours.

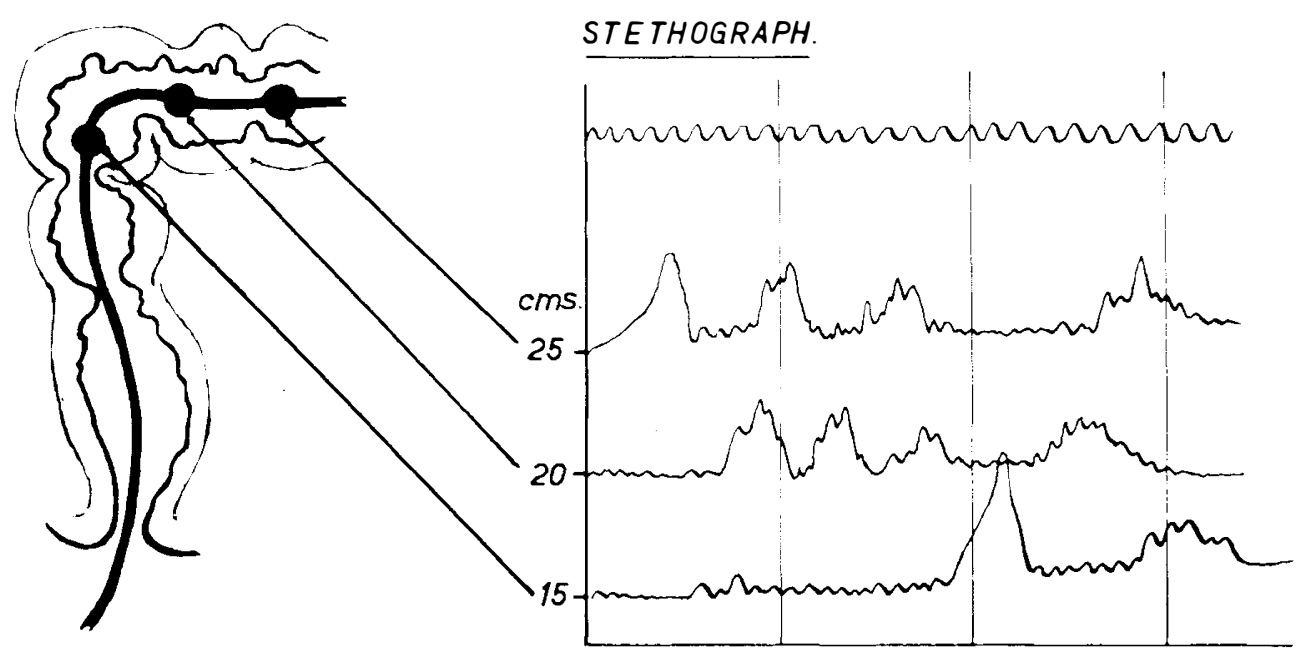

FIG. 2

Diagram illustrating method of recording.

It is essential to record the respiratory and body movement at the same time as colonic motility. This was done by using a stethograph around the upper abdomen and attached to a capsule of the manometer. Without the use of a stethograph, no reliable information can be obtained about the faster components of colonic activity.

One patient (Case 22) was studied by using a wireless telemetering capsule (Connell \& Rowlands, I960) (fig. 3). This is a miniature frequency oscillator which is powered by a mercury cell giving it a life of two to three days. The frequency of the oscillator is altered by movements of the lid in relation to the body of a ferrite pot core. The lid is attached to a perspex diaphragm which acts as the transducer, so that the change in the frequency of oscillation is proportional to the applied pressure at the diaphragm. In this study, the capsule was placed $25 \mathrm{~cm}$. above the anus through a sigmoidoscope and the aerial of the receiver placed on the abdomen.

Rectal Distension. To distend the rectum, a large balloon attached to a soft rubber catheter was passed into the rectum. The catheter was attached to one arm of a tidal drainage apparatus, another arm of which was connected to one of the metal capsules. Fluid was run into the balloon from the reservoir of the apparatus and the resulting pressures and volume noted. 


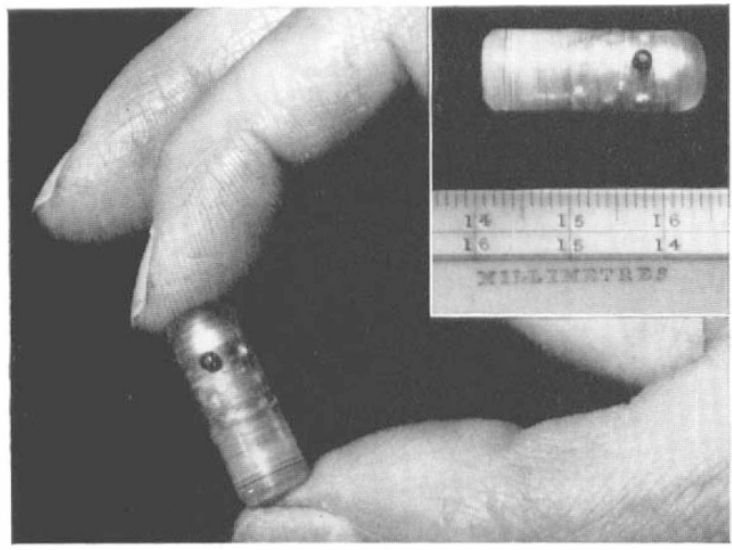

FIG. 3

The radio telemetering capsule.

Analysis of Records. Each record was carefully checked against the stethograph and all variations which represented cardiovascular, respiratory or somatic movement were excluded from further consideration.

The records were analysed over half-hour periods with respect to:

I. The duration of activity expressed as a percentage of the total time of analysis.

2. The mean amplitude of waves of a frequency less than 5 per minute (principal waves).

3. The percentage of slow waves of greater amplitude than $20 \mathrm{~cm}$. of water pressure.

4. The percentage time of analysis occupied by waves of a frequency of five per minute or more (fast waves).

5. The produce of duration of activity and the mean amplitude of the principal waves. This is an assessment of total colonic activity.

The full details of the methods of recording and analysis have been set out elsewhere (Connell, I96I).

\section{RESULTS}

Effect of Sidmoidoscopy. While no pressure measurements were made of the anal sphincters, the anus was watched during sigmoidoscopy and during rectal distension, and on occasions digital examinations were performed during rectal distension.

Rectal distension alone did not appear to have any effect on the anus in any of the patients. In the cervical cases the anus remained closed and the balloon was retained, while in the low flaccid lesions the anus was patulous and incapable of contracting so that the balloon was easily extruded by a slight movement of the trunk or by a cough.

Sigmoidoscopy itself had certain effects in nearly all cases. In the cervical patients there was no change in the anus until the sigmoidoscope reached I 3 to 18 $\mathrm{cm}$. when there was a reflex relaxation of the anus often accompanied by a feeling 
of tingling in the face and a throbbing headache. These feelings were interpreted by the patients as a warning that their bowels were acting. Many of the cervical patients did actually defaecate during sigmoidoscopy. These effects were not found in those cervical patients who had had alcohol blocks.

In the low flaccid lesions there was no change in the atonic anus during sigmoidoscopy, but the tone of the upper rectum and sigmoid colon was greater than in normal subjects, when the sigmoidoscope reached 15 to $20 \mathrm{~cm}$. they complained of periumbilical discomfort similar to that complained of by normal subjects during sigmoidoscopy.

Resting Motility. Figures 4, 5, 6 and 7 illustrate respectively records from a normal subject, a patient with a high cord lesion, a patient with a low spastic

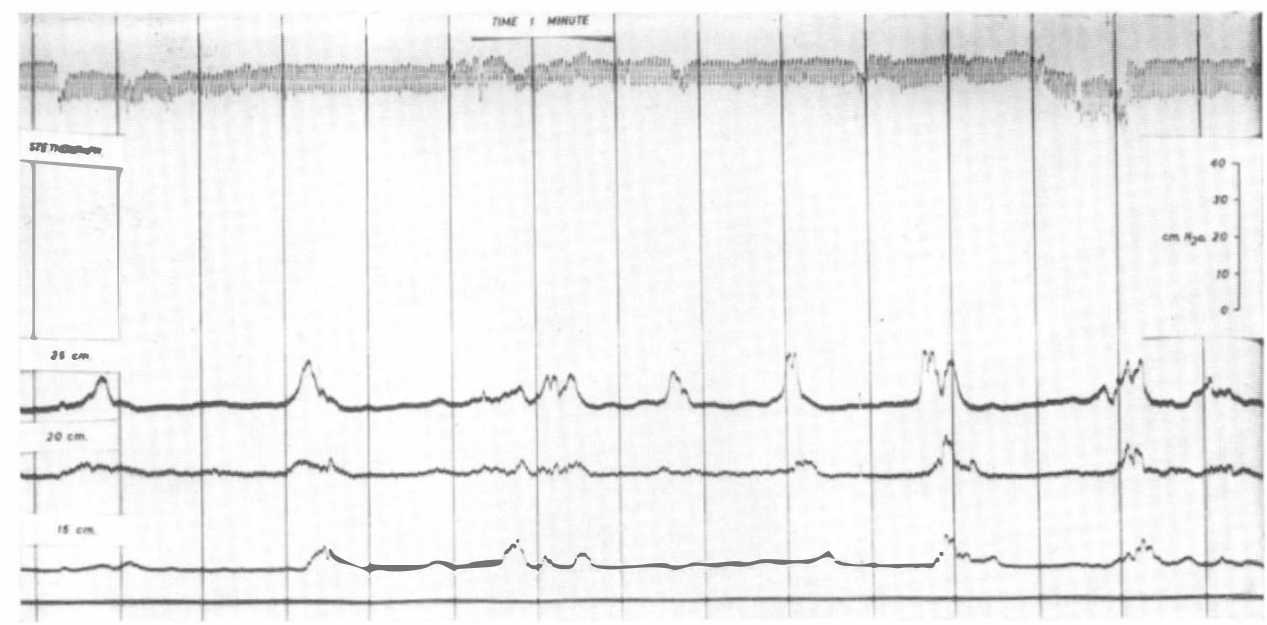

FIG. 4

Motility record from a normal subject. Simultaneous recording from 25,20 and $15 \mathrm{~cm}$. from the anus. In this and other figures top trace is a stethograph calibration in $10 \mathrm{~cm}$. water divisions and verticals are one minute intervals.

cord lesion and a patient with a low flaccid cord lesion. Records from the upper rectum in general have the same relative features as those from the sigmoid and only the latter have been analysed in detail:

High Cord Lesions. The records from patients with high lesions show generally less colonic activity than normal. Analysis shows that both the duration of activity and the amplitude of the waves are diminished (fig. 8). In these patients no fast waves (five per minute or more) are seen. Waves representing pressures of more than $20 \mathrm{~cm}$. of water are rarely seen. There was one of the patients in this group with an active colon (Patient No. 4, fig. I), but he had an active duodenal ulcer at the time of study.

Low Cord Lesions. In contrast, records from patients with low cord lesions are hyperactive. The duration of activity, the amplitude of the waves and the proportion of fast waves are greater than normal and significantly greater than in patients with high cord lesions.

There is no difference in the percentage duration of activity between the low 


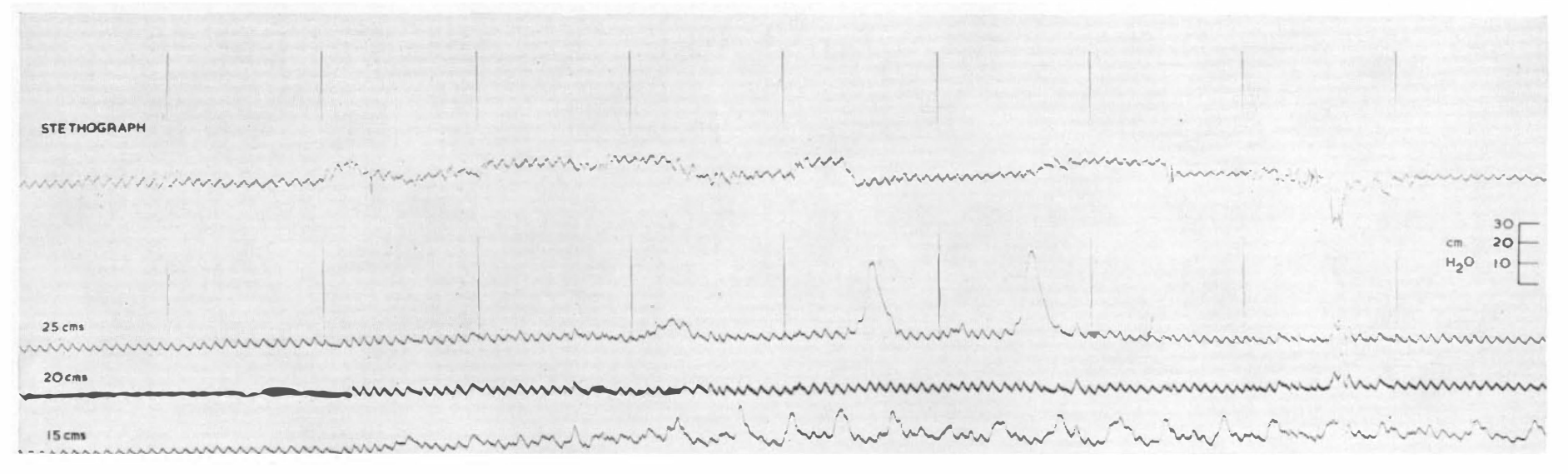

FIG. 5

Motility record from a patient with a high cord lesion. Simultaneous record at 25,20 and $15 \mathrm{~cm}$. from the anus. 


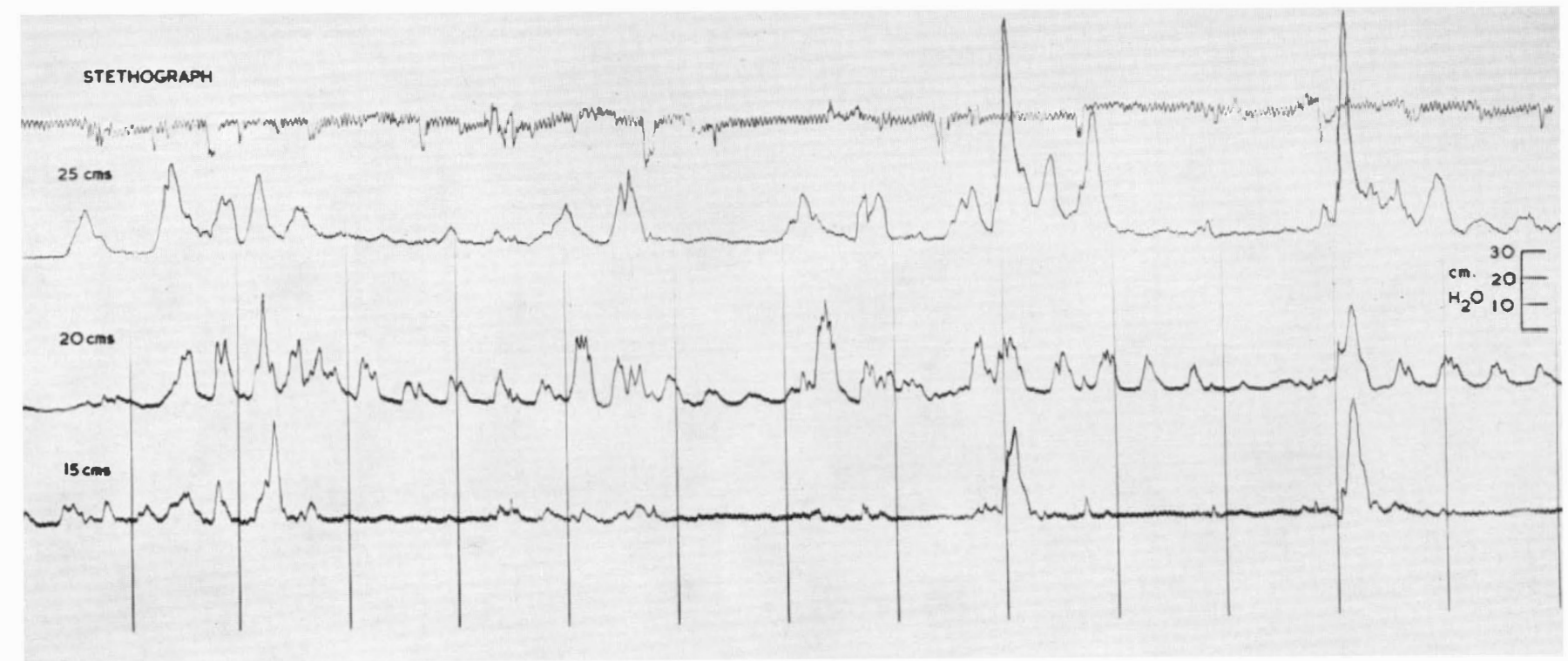

FIG. 6

Motility record from a patient with a complete lesion of the low thoracic cord with spastic paraplegia. Simultaneous recordings at 25,20 and $15 \mathrm{~cm}$. from the anus. 


\section{STETHOGRAPH}

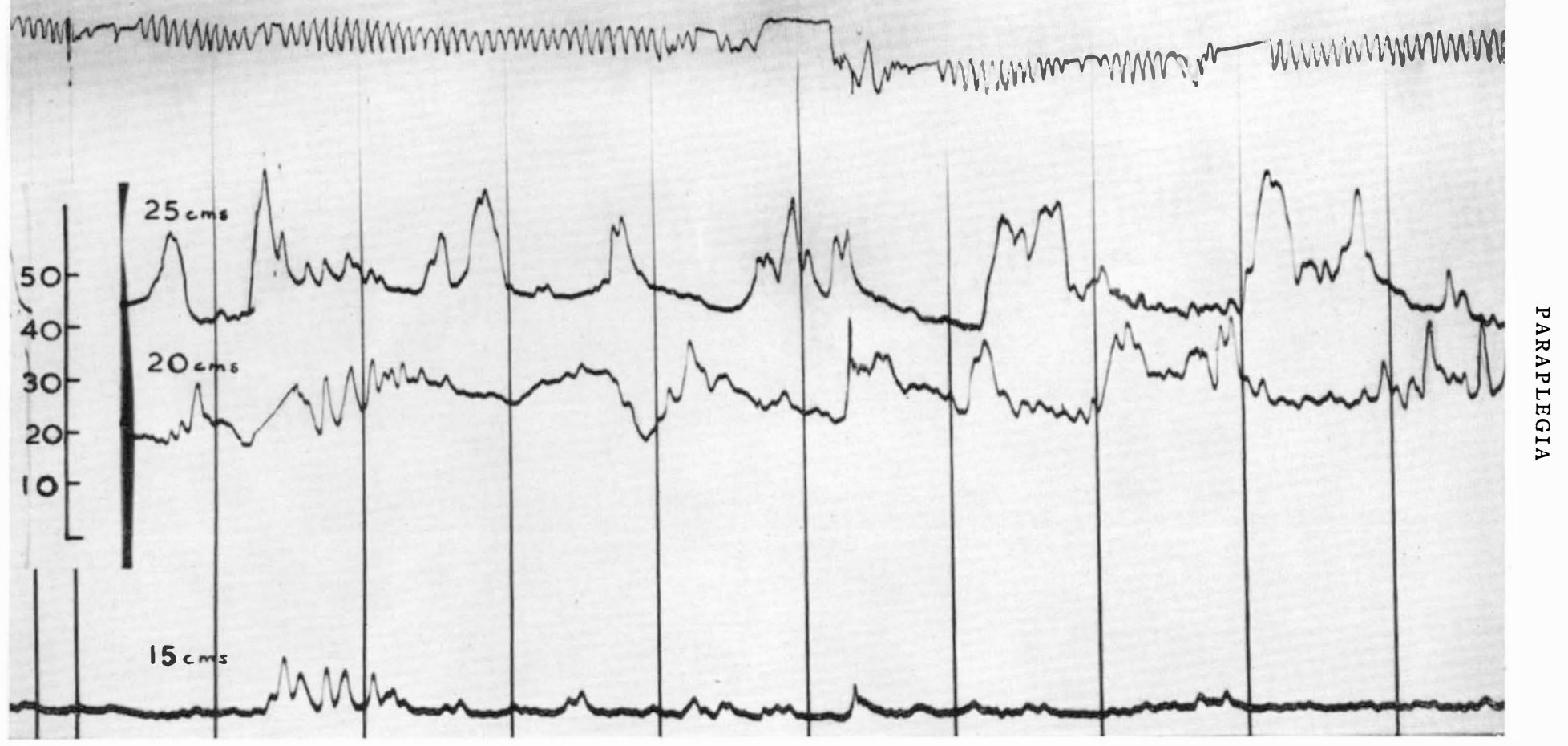

FIG. 7

Motility record from a patient with a complete flaccid paraplegia involving the lumbo-sacral cord. Simultaneous recording at 25,20 and $15 \mathrm{~cm}$. from the anus. 
MOTILITY OF PELVIC COLON FOLLOWING LESIONS OF SPINAL CORD

\begin{tabular}{|c|c|c|c|c|c|c|}
\hline & No. & $\begin{array}{l}\text { Percentage } \\
\text { duration of } \\
\text { activity }\end{array}$ & $\begin{array}{c}\text { Mean } \\
\text { amplitude }\end{array}$ & $\begin{array}{c}\text { Product } \\
\text { (Duration } \times \\
\text { Amplitude) }\end{array}$ & $\begin{array}{c}\text { Percentage } \\
\text { of waves } \\
\text { greater } \\
20 \mathrm{~cm} . \mathrm{H}_{2} \mathrm{O}\end{array}$ & $\begin{array}{l}\text { Percentage } \\
\text { duration of } \\
\text { fast waves }\end{array}$ \\
\hline $\begin{array}{l}\text { Upper cord } \\
\text { above T9 } \\
\text { Low cord } \mathrm{T}_{9} \\
\text { and below } \\
\text { Upper cord } \\
\text { with Alcohol } \\
\text { Block. } \\
\text { Normal }\end{array}$ & $\begin{array}{l}\text { I I } \\
\text { I I }\end{array}$ & $\begin{array}{l}36 \cdot 0 \pm 24 \cdot 5 \\
78 \cdot 2 \pm 16 \cdot 7 \\
16 \cdot 3 \\
51 \cdot 4 \pm 22 \cdot 3\end{array}$ & $\begin{array}{l}8 \cdot 7 \pm 3 \cdot 5 \\
\text { I } 5 \cdot 5 \pm 9 \cdot 2 \\
2 \cdot 3 \\
\text { II } 5 \pm 6 \cdot 5\end{array}$ & $\begin{array}{c}308 \pm 262 \\
1316 \pm 983 \\
60 \\
640 \pm 378\end{array}$ & $\begin{array}{c}0.0 \\
20.9 \pm 18.5\end{array}$ & $\begin{array}{c}0 \cdot 0 \\
I \cdot 7 \pm 4 \cdot I\end{array}$ \\
\hline
\end{tabular}

FIG. 8

Comparison of the motility of the colon of patient with high cord lesions, low cord lesions, high cord lesions with low Alcohol Block and normal subjects.

spastic and low flaccid groups although the latter tend to be the more irregular records (figs. 6, 7 and 9). The tracings of the low flaccid patients have a higher mean amplitude of principal waves and greater proportion of fast waves.

\begin{tabular}{|c|c|c|c|c|c|c|}
\hline & No. & $\begin{array}{l}\text { Percentage } \\
\text { duration of } \\
\text { activity }\end{array}$ & $\begin{array}{c}\text { Mean } \\
\text { amplitude }\end{array}$ & $\begin{array}{c}\text { Product } \\
\text { (Duration } \times \\
\text { Amplitude) }\end{array}$ & $\begin{array}{l}\text { Percentage } \\
\text { of waves } \\
\text { greater } \\
20 \mathrm{~cm} . \mathrm{H}_{2} \mathrm{O}\end{array}$ & $\begin{array}{l}\text { Percentage } \\
\text { duration of } \\
\text { fast waves }\end{array}$ \\
\hline $\begin{array}{l}\text { Low Flaccid } \\
\text { Low Spastic }\end{array}$ & $\begin{array}{l}5 \\
6\end{array}$ & $\begin{array}{l}82 \cdot 2 \pm 9 \cdot 6 \\
74 \cdot 8 \pm 20 \cdot 4\end{array}$ & $\begin{array}{l}19 \cdot 3 \pm 11 \cdot 3 \\
12 \cdot 3 \pm 5 \cdot 5\end{array}$ & $\begin{array}{l}1695 \pm 1350 \\
1000 \pm 588\end{array}$ & $\begin{array}{l}37 \cdot 6 \\
19 \cdot 5\end{array}$ & $\begin{array}{l}25 \cdot 8 \\
I I \cdot 0\end{array}$ \\
\hline
\end{tabular}

FIG. 9

Comparison of the motility of the colon of patients with low spastic lesions and low flaccid lesions.

The product of mean amplitude of the slow waves and of the duration of activity for the individual patients in these groups are set out in Figure Io demonstrating the marked difference between the two groups of cord lesions.

Effect of Alcohol Block. In contrast to the greatly increased activity of the patient with low cord lesions, the three patients with high cord lesions with intrathecal low alcohol blocks had the most inactive records of the series (fig. II). In none of these records were there any waves greater than $20 \mathrm{~cm}$. water pressure and none had any fast waves. It may be noted that the effect of the alcohol block on colonic activity can be a permanent one, as shown in Cases I 2 and I 4 where the alcohol block was carried out five and eight years respectively before this study.

One patient (Case 22) was studied both before and after the alcohol block. The resting motility record obtained before the alcohol block showed some residual colonic activity. Following the alcohol block, however, all activity ceased but on taking a meal there was still definite though greatly reduced sigmoid activity. 


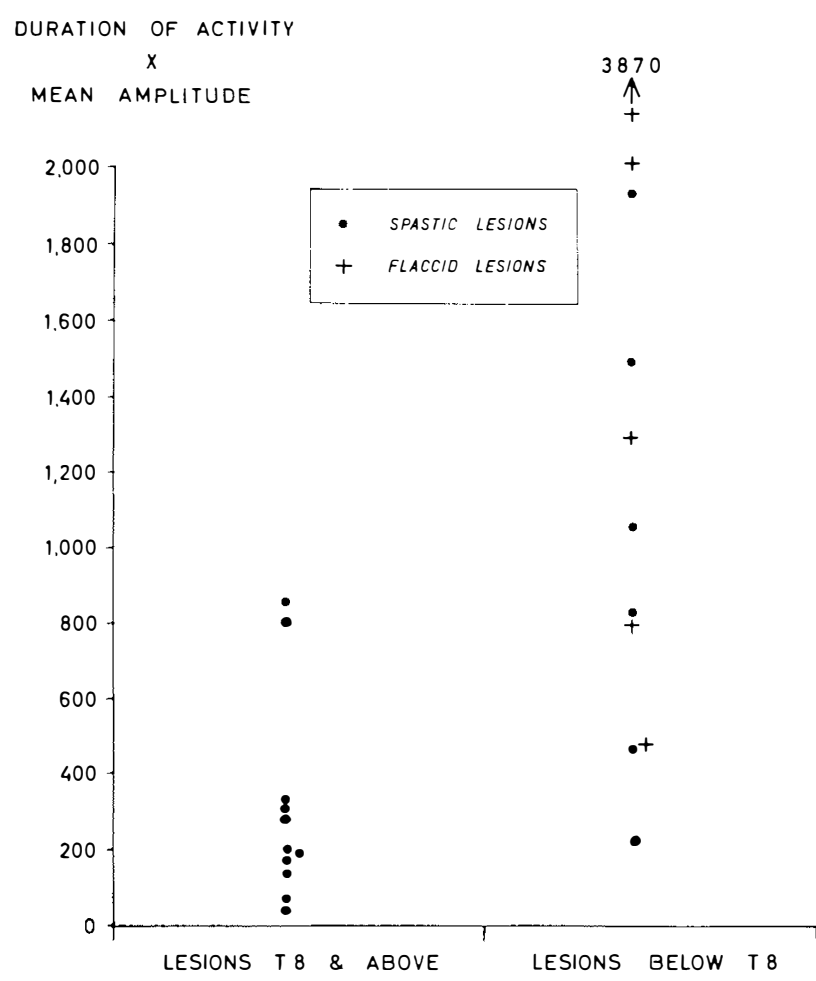

FIG. IO

Comparison of the total activity (Duration of Activity $\times$ Mean Amplitude) in patients with high cord and patients with low cord lesions.

Effect of Food. The effect of food was as a rule to produce an increase in both the percentage duration of activity and in the amplitude of the waves (fig. I2). This increase was of the same order as in normal subjects. (Connell, unpublished data). The increase in activity sometimes began immediately but was sometimes delayed by a latent period of up to I 5 minutes.

Two patients were shown the meal but not allowed to eat it for a few minutes. In one of these patients with a lesion below LI (Case 26, fig. I), there was an immediate and distinct increase in activity on seeing the meal (fig. I3). The increase in activity was reinforced by the subsequent consumption of the meal and was usually more marked in one channel than in the others. In another patient with a TiI lesion, there was no effect on seeing the food but the patient did not find the food appetising. However, there was a definite response to eating.

Drinking a glass of water did not have any effect on sigmoid activity in six patients tested.

Effect of Rectal Distension. The effects of distending the rectum on the motility of the sigmoid are set out in Figure I4. All seven patients with spastic: paraplegia showed some respunse io rectai distension. İn six cases there was an 


\section{STETHOGRAPH}

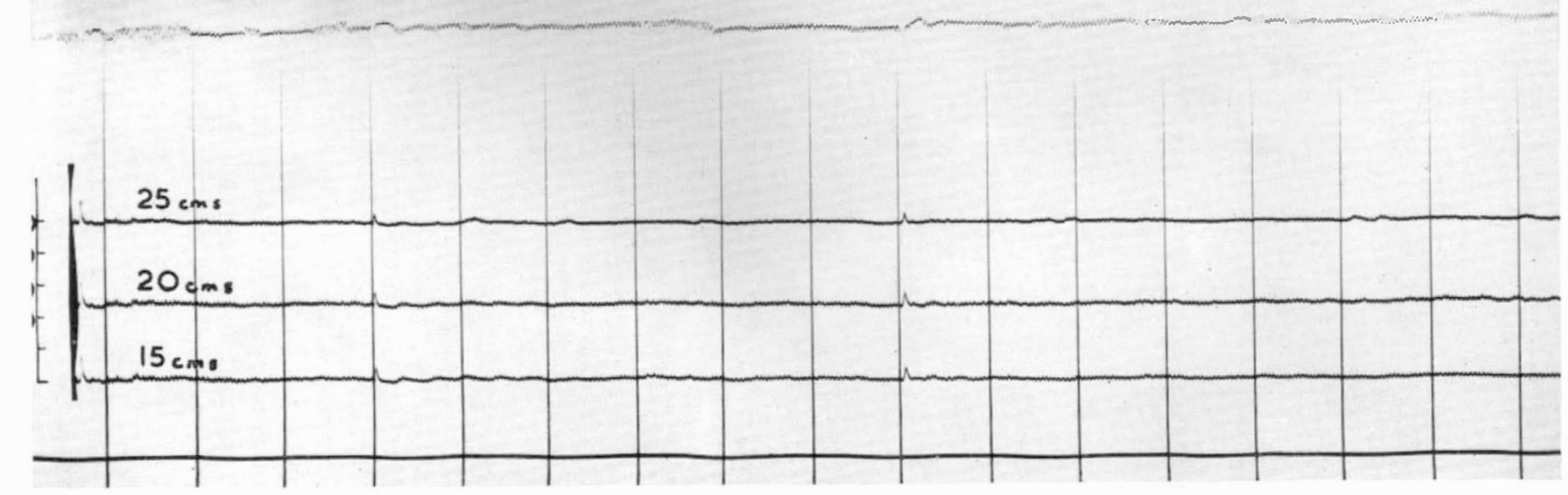

FIG. II

Motility record from a patient with a cervical cord lesion with flaccid paralysis of the lumbosacral segments resulting from an alcohol block. 


\begin{tabular}{|c|l|c|c|}
\hline Subject & $\begin{array}{c}\text { Level of } \\
\text { lesion }\end{array}$ & Before meal & After meal \\
\cline { 3 - 4 } & & $\%$ & $\%$ \\
4 & C7 (D.U.) & 85 & 97 \\
5 & C7 & 33 & 55 \\
7 & T2 & 44 & 80 \\
20 & TI2 & 87 & 95 \\
26 & LI & 70 & 100 \\
\hline
\end{tabular}

FIG. 12

The effect of a meal on the duration of activity in patients with spinal paraplegia.

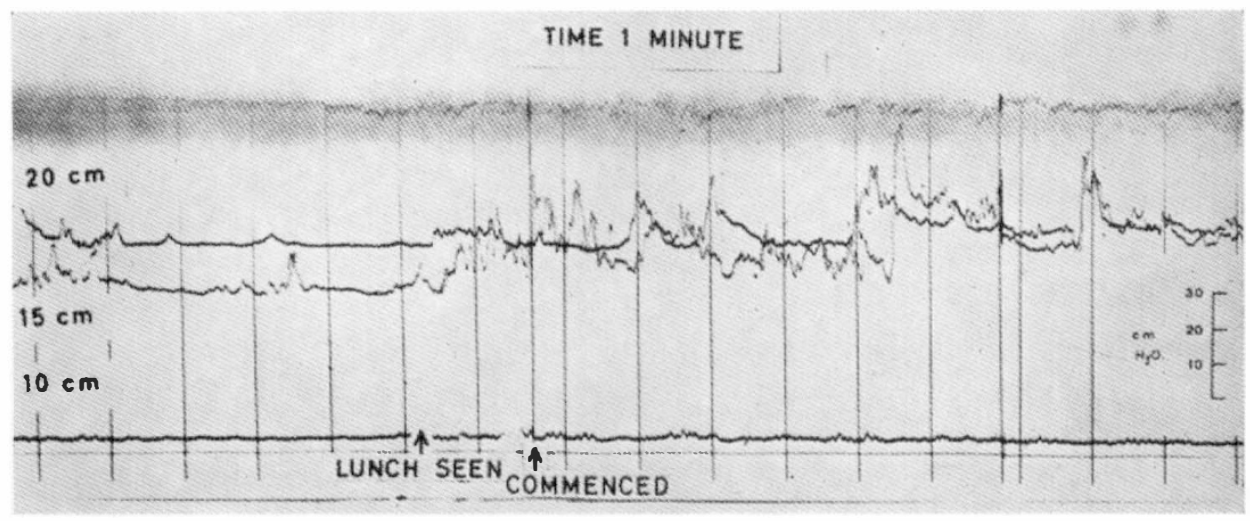

FIG. I3

The effect of a meal on the motility of the sigmoid colon in a spinal paraplegic (L1). (Patient No. 26). At first arrow patient was shown his meal. At the point indicated by the second arrow he began to eat.

initial inhibition of the motility of the sigmoid followed by a subsequent stimulation. The seventh patient (Case 5, fig. I4) showed an immediate stimulation. The volumes required to produce stimulation vary from person to person as do the pressures recorded. When sigmoid stimulation occurred, the balloon recording from nearest the distending balloon tended to be activated first, indicating that the response is most marked nearest to the point of stimulation. Figures $15 a$ and $b$ (Case 7, fig. I) illustrate a particularly instructive example. Between the areas A and $\mathrm{B}$ the undistended balloon is lying in the rectum. At point $\mathrm{A}$, the balloon was inserted into the rectum, which resulted in immediate stimulation of the sigmoid activity. However, when at point B Ioo $\mathrm{ml}$. of water was run into the balloon, the effect was immediate inhibition of sigmoid motility. The inhibition persisted until $350 \mathrm{ml}$. had been added to the balloon, at which point (marked by the arrow $\mathrm{C}$, fig. $\mathrm{I} 5 b$ ) the sigmoid was stimulated to marked activity. The activity was maintained until the rectum was decompressed by emptying the fluid from the balloon (D). In the patients with cervical lesions, cardiovascular response to rectal distension occurred, and in two cases the study had to be terminated because of a rise in 


\begin{tabular}{|c|c|c|c|c|c|c|c|}
\hline \multirow{2}{*}{$\begin{array}{l}\text { Patients } \\
\text { study } \\
\text { number }\end{array}$} & \multirow{2}{*}{$\begin{array}{l}\text { Level } \\
\text { of } \\
\text { lesion }\end{array}$} & \multicolumn{5}{|c|}{ Effect of } & \multirow{2}{*}{ Remarks } \\
\hline & & IOO ml. & $200 \mathrm{ml}$ & $300 \mathrm{ml}$. & $400 \mathrm{ml}$ & $500 \mathrm{ml}$. & \\
\hline 3 & C6 Spastic & - & - & - & - & + & $\begin{array}{l}\text { Discontinued as B.P. rose to } 2 \mathrm{ro} / \mathrm{I} \mathrm{ro} \\
\text { Critical stimulating pressure }=56 \mathrm{~cm} . \mathrm{H}_{2} \mathrm{O}\end{array}$ \\
\hline 4 & C7 Spastic & - & - & & & & Discontinued as B.P. rose to $210 / 130$ \\
\hline 5 & C7 Spastic & + & + & + & & & $\begin{array}{l}\text { Pressure rose immediately to } 35 \mathrm{~cm} . \mathrm{H}_{2} \mathrm{O} \\
\text { Critical stimulation pressure }=35 \mathrm{~cm} . \mathrm{H}_{2} \mathrm{O}\end{array}$ \\
\hline 6 & TI Spastic & - & - & - & + & & Critical stimulating pressure $=55 \mathrm{~cm} . \mathrm{H}_{2} \mathrm{O}$ \\
\hline 7 & T2 Spastic & - & - & - & + & & Critical stimulating pressure $=55 \mathrm{~cm} . \mathrm{H}_{2} \mathrm{O}$ \\
\hline II & $\mathrm{T}_{7}$ Spastic & - & + & + & & & Critical stimulating pressure $=42 \mathrm{~cm} . \mathrm{H}_{2} \mathrm{O}$ \\
\hline 20 & TI2 Spastic & - & + & & & & Critical stimulating pressure $=75 \mathrm{~cm} . \mathrm{H}_{2} \mathrm{O}$ \\
\hline I3 & $\begin{array}{l}\text { C6 Alcohol } \\
\text { Block TI2 } \\
\text { Flaccid }\end{array}$ & $\begin{array}{l}+ \\
-\end{array}$ & $\begin{array}{l}+ \\
-\end{array}$ & - & & & \\
\hline I4 & $\begin{array}{l}\text { T6 Alcohol } \\
\text { Block TI2 } \\
\text { Flaccid }\end{array}$ & 0 & 0 & 0 & & & No response \\
\hline $2 \mathrm{I}$ & T9 Flaccid & ० & 0 & & & & $\begin{array}{l}\text { No response. Balloon constantly extruded } \\
\text { passively when } 200 \mathrm{ml} \text {. added }\end{array}$ \\
\hline 23 & TI2 Flaccid & 0 & 0 & & & & $\begin{array}{l}\text { No response. Balloon extruded passively } \\
\text { when } 200 \mathrm{ml} \text {. added }\end{array}$ \\
\hline 25 & LI Flaccid & 0 & 0 & 0 & 0 & & No response \\
\hline
\end{tabular}

FIG. I4

Effect of Rectal Distension.

(Sigmoid stimulation marked: + ) 


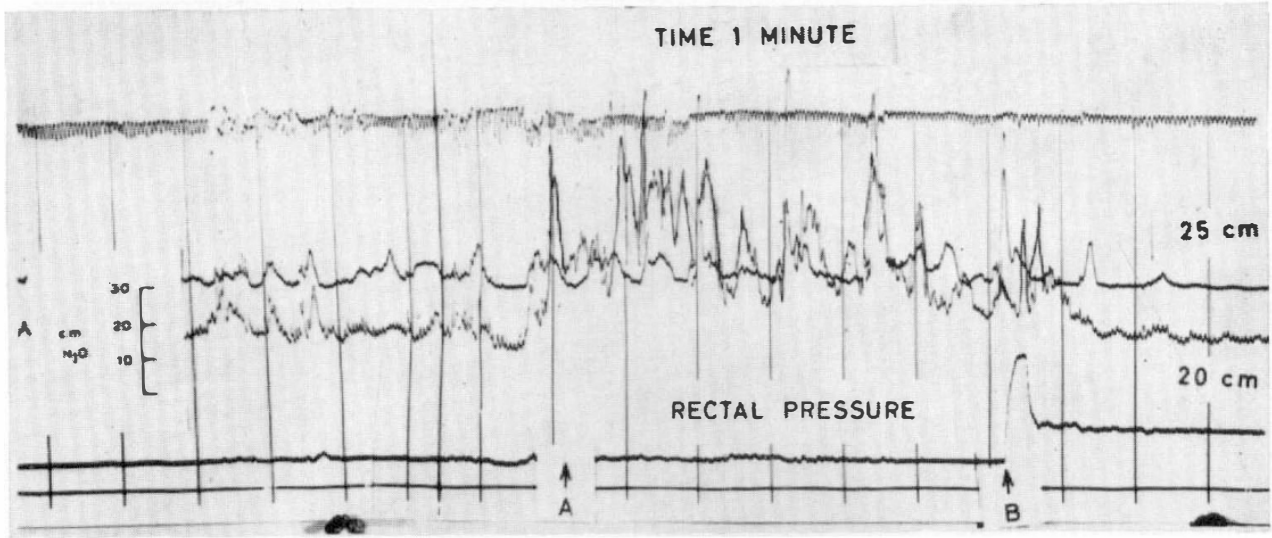

FIG. I5a

Effect of moderate rectal distension on the motility of the pelvic colon (Patient No. 7, fig. I). At the arrow A a soft rubber catheter tied to a latex balloon is passed into the rectum. At the arrow B, IOO ml. of water are passed into the balloon resulting in immediate inhibition of the sigmoid activity.

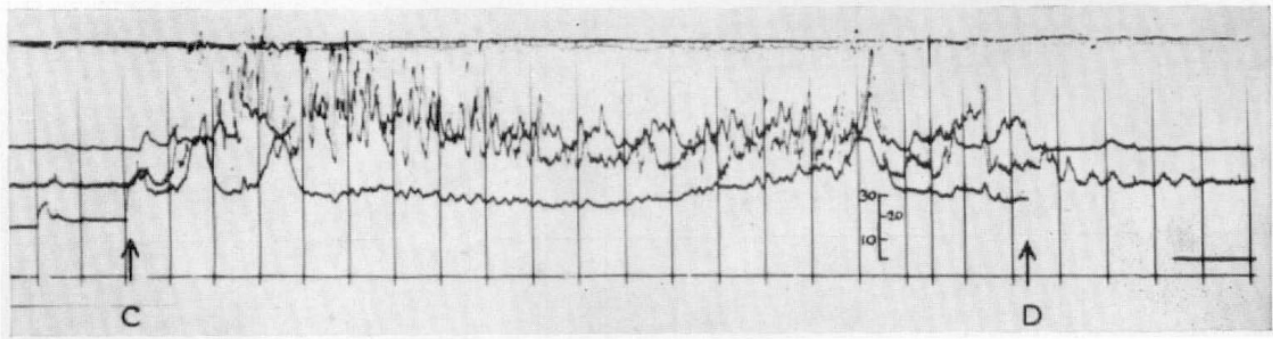

Fig. I5b

Effect of powerful rectal distension on the motility of the pelvic colon. At the point $\mathrm{C}$ the volume of fluid distending the rectum is increased from 300-350 ml. The hyper-activity persists until decompression of the rectum (D).

blood pressure to high levels. In three cases, the cardiovascular effects were accompanied by sensations mainly in remote areas. These were described as 'tingling of the face', 'headache', 'a shivery feeling' and 'something going on down below', as described previously by Guttmann and Whitteridge (1947).

\section{DISCUSSION}

The most striking feature in our study is the significant difference in the sigmoid activity in resting conditions between patients with high cord lesions and those with low cord lesions. The apparent general hypomotility of the sigmoid in patients with cervical and high thoracic cord transection compared with normal subjects and lower cord lesions could be explained by the difference in respiratory activity as a result of the paralysis of the abdominal and intercostal muscles. A complete absence of fast waves was found in cervical and thoracic cord lesions. This indicates an inhibitory influence which the lumbar outflow exerts on the 
colon. Actually, an inhibitory centre in the lumbo-sacral region of the cord was postulated by Garry (1933), as a result of experiments in cats. Our findings indicate that eliminating the lumbar outflow results in release of the sacral outflow in man, with consequent uninhibited high sigmoid activity. In fact, all our low cord lesions showed exaggeration of the fast waves. If the sacral outflow itself was cut off in high cord lesions by intrathecal alcohol injection not only did the fast waves disappear completely, but in none of the records were there any waves greater than $20 \mathrm{~cm}$. water pressure. However, other influences still exist which may regulate bowel activity, such as intestino-intestinal reflexes (Youmans, 1944), the vagus and hormonal effects.

It was not surprising to find that eating food produced an increase in colonic motility, as there is evidence that the gastro-colic reflex can be conducted in the intramural plexuses of the alimentary tract (Douglas \& Mann, I940), although Gregory (I950) holds the view that the reflex depends on the integrity of the thoraco-lumbar outflow. In our patients, the effect of food was as a rule to produce an increase in both the percentage and duration of activity and in the amplitude of the waves-an increase which was of the same order as in normal subjects (Connel, unpublished data). With regard to psycho-colic reflex, nothing conclusive can be deduced from our investigations. It was clearly found demonstrable in a patient with a complete lesion below LI, which one would expect in such a distal lesion. However, it was absent in a lesion at the level of TII, although it must be stated that the patient did not find the food appetising. However, there was a definite response in this case to eating.

The effect of rectal distension is of interest in that there is a difference in response between patients who had reflex activity in the lower cord segments and those who did not. In the former group, the usual response to filling of the rectum with roo $\mathrm{ml}$. fluid was an initial inhibition of the sigmoid. This was followed, when the rectal pressure rose following increased amount of fluid $(300 \mathrm{ml}$.$) , by an increased$ activity of the sigmoid. This is probably a similar phenomen to that well-known phenomen in the small intestines of cats, whereby distension of one segment of the small intestine results in inhibition of neighbouring segments. To this response the term intestino-intestinal reflex has been applied. However, in patients with low cord destruction, where all reflex activity was abolished, no effect was noted, indicating that the intestino-intestinal reflex is, in fact, spinal. The stimulating effect on the colon to gross distension of the rectum may represent a defence mechanism against rectal over-filling. The waves recorded from the sigmoid are segmental in type and would have the effect of preventing the onward passage of more faeces into the already distended rectum (Connell, 1962). On the other hand, stimulation of higher areas of the bowel with the sigmoidoscope resulted in reflex relaxation of the anus and passage of stool. This suggests that the area essential if not most important for the initiation of the defaecation reflex in man is not the rectum but the lower sigmoid colon. This does not exclude, of course, the possibility that defaecation may be initiated by rectal distension itself.

\section{SUMMARY}

Sigmoid activity was studied in 26 patients with complete lesions at various levels of the spinal cord.

The resting unstimulated motility of the pelvic colon was found to differ in 
patients with high cord lesions both from that of normal subjects and patients with low thoraco-lumbar lesions. In high cord transection with intact isolated cord below the lesion, resting colonic activity was reduced compared with normal subjects, while patients with low cord lesions showed a significantly increased colonic motility.

The mechanism underlying the changes of resting colonic motility is discussed.

Factors influencing colonic motility were also studied and the effects of intake of food, the psycho-visceral reflex, rectal distension, sigmoidoscopy, and intrathecal alcohol injection are described.

\section{RÉSUMÉ}

L'activité du colon sigmoide a été etudié chez 26 paraplégiques présentant des lésions completes de la moelle épinière a differents niveaux.

L'activité spontanée, sans stimulation, est diffèrente chez les sujets avec transection haute, no seulement de celle des sujets normaux mais aussie de l'activité des cas de lésions basses thoraco-lombaires.

Dans le cas des lésions hautes avec une möelle épinière sous-jacente intacte l'activité spontanée est réduite, comparée aux sujets normaux; aux contraire, dans le cas des lésions basses l'activité du colon est manifestement augmentée.

La discussion porte sur le mécanisme responsable de cette activité spontanée.

D'autre part les facteurs stimulant l'activité du colon sont aussi étudiés ainsi que l'effet de la prise de nourriture, le refléxe psychoviscéral, la distension réctale, la sigmoidoscopie et enfin l'activité après injection intrarachidienne d'alcool.

\section{ZUSAMMENFASSUNG}

Die Aktivitaet des Sigmoids wurde in 26 Patienten mit completten Querschnittslaesionen des Rueckenmarks verschiedener Hoehe untersucht.

Es wurde ein Unterschied in der Eigenmotilitaet des ungereizten Sigmoids zwischen hohen und distalen Querschnittslaesionen sowie normalen Kontrollen gefunden. In hohen Laesionen mit intaktem isolierten Rueckenmark unterhalb der Querschnittslaesion ist die Eigenaktivitaet des Colons reduciert im Vergleich mit der von normalen Individuen, waehrend in distalen Querschnittslaesionen eine deutlich erhoehte Eigenmotilitaet festetellbar war.

Der Mechanismus dieser unterschiedlichen Eigenmotilitaet des Sigmoids wird besprochen. Faktoren, welche die Motilitaet des Sigmoids beeinflussen, wurden ebenfalls untersucht, und es werden die Effekte von Nahrungsaufnahme, psycho-visceralen Reflex, rektaler Distension, Sigmoidoskopie und subarachnoidaler Alcoholinjektion beschrieben. 


\section{REFERENCES}

Atkinson, M., Edwards, D. A. W., Honour, A. J., \& Rowlands, E. N. (I957). Lancet, 2, 918.

Bayliss, W. M., \& Starling, E. H. (I900). F. Physiol., 26, I07.

CoNNELl, A. M. (1961). Gut, 2, I75.

ConNell, A. M. (I962). Gut, 3, 342 .

CONNELl, A. M., \& Rowlands, E. N. (1960). Gut, I, 266.

Denny Brown, D., \& Robertson, E. G. (1935). Brain, 58, 256.

Douglas, D. M., \& ManN, F. C. (I940). A. M. f. Digest. Dis., 7, 53.

Elliott, T. R., \& Barclay-Smith, E. (I904). F. Physiol., 3I, 272.

Garry, R. C. (I933). F. Physiol., 78, 208.

GOWERS, W. R. (I877). Proc. R. Soc., 26, 77.

Gregory, R. A. (1950). F. Physiol., III, I I9.

Guttmann, L. (1947). Proc. R. Soc. Med., 40, 219.

GutTmann, L. (1954). Monograph in Vol. Surgery, Medical History of the Second World War, pp. 422-516. London: H.M. Stationery Office.

Guttmann, L. (1959). Proc. R. Soc. Med., 52, 86.

GutTMANN, L., \& WhitTeridge, D. (1947). Brain, 70, 36r.

Lister, J. (1858). See Rudolf, C. R. (I932). Brit. F. Surg., 20, 195.

Masius, P. (I868). Bull. Acad. R. Sci. (Belge), I, 49 I.

Rowlands, E. N., Honour, A. J., Edwards, D. A. W., \& Corbett, B. D. (1953). Clin. Sci., 12, 299.

White, J. C., Verlich, M. G., \& Ehrenthal, O. (I940). Ann. Surg., II2, I042.

Youmans, W. B. (I944). Gastroenterology, 3, I I 4.

\section{BOOK REVIEW}

Rückenmarkstrauma und Mangeldurchblutang. (Trauma of the Spinal Cord and Ischaemia). By D. ToenNis. Beitr. Neurochir. I963, 5, pp. 5-167. Publisher: Joh. Ambr. Barth, Leipzig.

The part played by ischaemia due to vascular damage in the production of neurological signs in Paraplegia is contrasted with the still widely held views of mechanical pressure by bone.

After describing what is known about the Histology and Anatomy of the vascular supply of the spinal cord, the author presents his own material seen at the Accident Hospital 'Bergmannsheil', Bochum, Germany, situated close to coal mines and roads. On the average the patients were admitted within $I \frac{1}{2}$ to 2 hours after injury. In I4 years, I,855 injuries of the spine were seen, of which 285 showed involvement of the cord. Of these 77 were cervical, 70 dorsal, and 125 lumbar lesions with 13 spinal contusions.

Very detailed neurological examinations repeated over the first few months showed at all levels and all degrees of fracture-dislocation, that paralysis corresponded far more with the weak spots of vascularity of the cord than with the level of displacement of the damaged vertebrae. Detailed post-mortem findings confirm this distribution.

A survey of experimental evidence of the part played by mechanical and vascular damage in injuries of the cord supports further the view that ischaemia is of much greater importance than is generally realised.

Applied to primary treatment this study confirms that operation inevitably leading to further damage to blood-supply does-in all but a few cases-more harm than good.

The author emphasises the need for the earliest possible manual reduction of the severe dislocation-under anaesthetic. This is practised by his teacher, Prof. Bürkle de la Camp and by Prof. Boehler. But-according to his own data-even after 2 hours it will be already too late to prevent irreversible ischaemic damage which is, according to the author, caused within 20 minutes. This statement needs, of course, further proof.

This careful and comprehensive study is full of interesting detail. Fact and interpretation are kept well apart. There is a good collection of references and an index. 